\title{
Pemanfaatan Ecobrick Menjadi Pojok Ekoliterasi Sebagai Upaya Menanggulangi Darurat Sampah Selama Pandemi Covid-19 Di Sekolah Dasar
}

\author{
Al Aziz ${ }^{1}$, Meyke Erlianda ${ }^{1}$, Putri Ayuni Agustina ${ }^{1}$, Irfan Mubarok ${ }^{1}$, Sani Aryanto ${ }^{1, *}$ \\ ${ }^{1}$ Fakultas IImu Pendidikan; Universitas Bhayangkara Jakarta Raya; Jl. Perjuangan No.8 Bekasi \\ Utara; e-mail: 202010615051@mhs.ubharajaya.ac.id, 202010615007@mhs.ubharajaya.ac.id, \\ 202010615044@mhs.ubharajaya.ac.id, irfan.mubarok18@mhs.ubharajaya.ac.id, \\ saniaryanto@dsn.ubharajaya.ac.id
}

* Korespondensi: e-mail: saniaryanto@dsn.ubharajaya.ac.id

Submitted: 22/10/2021; Revised: 08/12/2021; Accepted: 20/12/2021; Published: 31/01/2022

\begin{abstract}
Bekasi is one of the cities that encourages all elements of society to be involved to overcome waste. Community Service that has been carried out is a concrete effort in providing preventive solutions through the use of ecobricks as an Pojok Ekoliterasi. The target of this service were 109 students and 11 teachers at SDN Kayuringin Jaya VI who are expected to represent elementary schools in Bekasi City. The method used in carrying out this service uses the scaffolding method, which is a method by providing structured assistance based on the difficulties experienced through extension activities, training, and science and technologqwwy assistance which are carried out in a blended. The objective target for four months proves that Pojok Ekoliterasi through the use of ecobricks for partners can be maximized, so that the program's objectives reaches $100 \%$. this activity has the potential to become an excellent extracurricular program in elementary schools through intensive communication with partners. In addition, this program is considered potential to be continued with wider targets due to the existence of various dissemination through collaboration with the Bekasi City Government (MOU/016/V/2019/UBJ). Therefore, Pojok Ekoliterasi has the potential to be developed in elementary schools in the Bekasi City. in order to expand information related to the results of this service, we have also developed various supporting outputs that are more easily accessible to the public for free through guides, scientific articles, videos on YouTube, and the creation of intellectual property rights. The results of this study are expected to be a reference for other elementary schools in developing innovative programs to solve the problem of waste in Indonesia.
\end{abstract}

Keywords: Ecobrick, Ecoliteration Corner, Waste

\begin{abstract}
Abstrak
Bekasi adalah salah satu kota yang mendorong seluruh elemen masyarakat untuk terlibat dalam penanganan sampah. Pengabdian Pada Masyarakat yang telah dilakukan menjadi i upaya konkret dalam memberikan solusi secara preventif melalui pemanfaatan ecobrick menjadi pojok ekoliterasi. Adapun mitra sasaran dari pengabdian ini adalah 109 siswa/i dan 11 guru di SDN Kayuringin Jaya VI yang diharapkan dapat mewakili SD yang ada di kota Bekasi. Metode yang digunakan dalam melaksanakan pengabdian ini menggunakan metode scaffolding yaitu suatu metode dengan memberikan bantuan secara terstruktur berdasarkan kesulitan yang dialami melalui kegiatan penyuluhan, pelatihan, dan pendampingan IPTEK yang dilaksanakan secara blended. Adapun target hasil capaian selama empat bulan membuktikan bahwa pojok ekoliterasi melalui pemanfaatan ecobrick pada mitra dapat dibuat dengan maksimal, sehingga ketercapaian program mencapai $100 \%$. kegiatan ini berpotensi menjadi program unggulan
\end{abstract}


ekstrakurikuler di SD melalui komunikasi intensif dengan mitra. Di samping itu, program ini dianggap potensial untuk terus dilanjutkan dengan target sasaran lebih luas dikarenakan adanya berbagai ruang diseminasi melalui jalinan kerjasama dengan Pemerintah Kota Bekasi (MOU/016/V/2019/UBJ). Oleh karena itu, Pojok Ekoliterasi potensial dikembangkan di SD yang berada di wilayah Kota Bekasi. Adapun dalam rangka memperluas informasi terkait dengan hasil pengabdian ini, kami juga mengembangkan berbagai luaran penunjang yang lebih mudah diakses oleh masyarakat secara gratis melalui panduan, artikel ilmiah, video di youtube, dan pembuatan HAKI. Hasil penelitian ini diharapkan menjadi referensi untuk SD lainnya dalam mengembangkan program-program inovatif untuk menuntaskan permasalahan sampah plastik di Indonesia.

Kata kunci: Ecobrick, Pojok Ekoliterasi, Sampah

\section{Pendahuluan}

Pandemi Covid-19 yang terjadi saat ini berimpliksi terhadap tatanan kehidupan yang tidak berjalan normal seperti biasanya. Kini terjadi lonjakan yang sangat signifikan dengan jumlah korban yang terpapar semakin bertambah dengan angka mortalitas yang menunjukan fluktuasi maksimum (Singh \& Subedi, 2020). Virus yang disinyalir berasal dari Wuhan dan tercatat mulai merebak di akhir tahun 2019 memberikan dampak terhadap modifikasi kebijakan dalam beberapa bidang, hal ini mengakibatkan perubahan pola interkasi dalam kehidupan sehari-hari. (Sanchis-Gomar et al., 2020). Berbagai upaya telah dilakukan dan salah satu upaya kuratif yang mulai diimplementasikan adalah penerapan era "New Normal' untuk mengantisipasi permasalahan-permasalahan yang kerap terjadi selama masa Covid-19 terutama di bidang lingkungan hidup (Bikdeli et al., 2020). Covid-19 menjadi bahan refleksi negeri ini karena musibah yang terjadi tidak lepas dari pola perilaku penduduk Indonesia yang tidak ramah terhadap lingkungan. Walaupun Indonesia diyakini memiliki potensi demografi yang sangat baik dan diperkirakan mengalami masa keemasan di Tahun 2045 (S Aryanto, 2016), nyatanya dengan adanya musibah Covid-19 seolah menjadi indikator bahwa Indonesia harus terus berbenah dan mencari upaya solutif secara preventif maupun kuratif dalam menghadapi permasalahan-permasalahan yang terjadi hingga saat ini (Kiky, 2020).

Indonesia memang diyakini sebagai negara yang kaya akan Sumber Daya Alam (SDA) dan Sumber Daya Manusia (SDM), dan diyakini sebagai negara yang memiliki potensi kemajuan akseleratif di tahun 2030-2045, tak heran banyak ilmuan menganggap bahwa tepat di usia 100 tahun pasca kemerdekaan menjadi masa keemasan bagi Bangsa Indonesia. Pada periode tersebut, usia produktif lebih banyak dibandingkan dengan usia yang tidak produktif sehingga menjadi bonus demografi untuk bangsa kita ditunjang dengan kekuatan SDA dan keanekaragaman budaya yang melimpah dari Sabang sampai Merauke. Menurut Aryanto, (2016, hlm. 431) "Pada periode tersebut generasi penerus bangsa berada pada titik yang sangat produktif, berharga dan bernilai". Oleh karena itu kondisi tersebut harus bisa dimanfaatkan dalam rangka menjadikan sumber daya manusia Indonesia yang berkarakter, cerdas, dan kompetitif. Namun apabila peluang ini tidak dapat dimanfaatkan dengan baik maka tidak menutup kemungkinan bonus demografi menjadi bencana demografi. 
Harapan terhadap generasi emas 2045 merupakan jawaban terhadap fenomena paradok-sial tentang Indonesia. Fenomena ini dikemukakan oleh Habibie (dalam Prasetyo, 2014) menyatakan bahwa: (1) Kita kaya tapi miskin, yaitu SDA melimpah tapi miskin penghasilan, (2) Kita besar tapi kerdil, amat besar wilayah dan penduduknya tapi kerdil dalam produktivitas dan daya saing, (3) Kita kuat tapi lemah, kuat dalam anarkisme tapi lemah dalam tantangan global, dan (4) Kita indah tapi buruk, indah dalam potensi dan prospeknya namun buruk dalam pengelolaannya.

Berdasarkan hasil Global Competitive Index, Indonesia berada diperingkat 45 dari 140 negara dengan tiga permasalahan utama yang membutuhkan prioritas penanganan yaitu pendidikan dasar, ekonomi, dan lingkungan. Pencapaian itu tidak cukup baik apabila melihat demografi Bangsa Indonesia saat ini. Salah satu permasalahan serius yang menjadi perhatian dunia terhadap Indonesia adalah rendahnya ecoliterasi dan permasalahan sampah, khususnya sampah plastik. Sehingga tak heran Indonesia dinobatkan sebagai negara urutan kedua sebagai penyumbang sampah terbesar di dunia. Tidak dapat dipungkiri, permasalahan amoralitas penduduk Indonesia dalam memperlakukan sampah plastik yang menyebabkan kuantitas sampah semakin tak terbatas. Dalam lingkup nasional, (dengan asumsi jumlah penduduk 180 juta jiwa, laju produksi sampah setiap orang adalah dua liter perhari dengan komposisi 6,17\%) sehingga jumlah timbunan sampah di Indonesia setiap tahunnya dapat mencapai 1.599 .000 ton (Oktapianto, 2016). Kekhawatiran paradoks sial yang diresahkan presiden RI Ke-3 seolah membuktikan bahwa SDM yang melimpah belum tentu berbanding lurus dengan pengelolaan SDA yang baik, salah satu indikator yang menjadi bukti nyata adalah kurangnya kesadaran masyarakat Indonesia dalam memperlakukan sampah.

Sampah memang dipandang sebagai sebuah benda yang tidak bernilai dan berharga, sehingga tak jarang diperlakukan dengan tidak sewajarnya oleh sebagian besar manusia. Ketidakwajaran ini yang membuat sebagian besar manusia terdorong untuk membuang sampah seenaknya tanpa memperdulikan dampak yang ditimbulkan terhadap kesehatan, sosial, ekonomi, dan budaya. Padahal kini Indonesia menjadi negara darurat sampah. Menurut data Kementrian Lingkungan Hidup dan Kehutanan, bahwa Indonesia memproduksi sampah hingga 65 juta ton pada 2016 tahun lalu. Dan jumlah sekarang naik 1 juta ton dari tahun sebelumnya. Berdasarkan laporan Menteri Lingkungan Hidup dan Kehutanan Siti Nurbaya mengatakan sampah yang dihasilkan berdominan sampah organik yang mencapai sekitar 60 persen dan sampah plastik yang mencapai 15 persen dari total timbunan sampah, terutama di daerah perkotaan. Sesuai data tersebut menunjukan dalam 10 tahun terakhir banyaknya sampah plastik terus meningkat (Kurnia, 2020). Apalagi selama covid-19 diyakini volume sampah mengalami lonjakan yang semakin tinggi, Kementerian Lingkungan Hidup dan Kehutanan (KLHK) mencatat terjadi peningkatan 30\% limbah B3 medis di masa pandemi. Berdasarkan peta jalan 2019-2020, KLHK memprediksi limbah B3 mencapai 293,87 ton/hari. Namun, di masa pandemic Covid-19 jumlahnya diperkirakan 382,03 ton/hari ("Virus Corona: Limbah Infeksius Covid-19 Masih Ditemukan Di TPA, Ada Kelonggaran, Pengabaian, Dan Tidak 
Ada Pengawasan," 2020). Permasalahan sampah ini bisa dikategorikan sebagai permasalahan serius karena akan berimplikasi terhadap bidang-bidang lainnya terutama bidang pendidikan sebagai salah satu sarana dalam meningkatkan ecoliterasi penduduk Indoensia agar peduli dan cinta terhadap lingkungan alam. Sehingga diperlukan upaya sistematis dan komprehensif dalam menciptakan pola pembelajaran yang mendepankan pada aspek apektif melalui internalisasi nilai-nilai kepedulian terhadap lingkungan alam dalam seluruh aspek interverensi pendidikan.

Bekasi adalah salah satu daerah yang memiliki permasalahan sampah yang sangat mengkhawatirkan. Kepala Bidang Kebersihan pada Dinas Lingkungan Hidup Kabupaten Bekasi Dodi Agus Supriyanto (Pahrevi, 2019) mengatakan bahwa: "Tempat Pembuangan Akhir (TPA) Burangkeng, Kecamatan Setu, Kabupaten Bekasi sudah melebihi kapasitas menampung sampah (overload) dengan ketingian mencapai 20 meter yang seharusnya 15 meter. Setiap harinya, TPA Burangkeng menerima 800 ton sampah dari wilayah kabupaten maupun Kota Bekasi". Kurangnya ketersediaan TPA menjadi alasan utama penyebab jumlah sampah semakin tidak terbatas hingga membanjiri sungai ratusan meter, padahal upaya perluasan TPA sebagai upaya penyembuhan/pengobatan sudah dilakukan. Potret nyata pencemaran air terjadi di aliran Sungai Pisang Batu, Desa Pahlawan Setia, Tarumajaya, Kabupaten Bekasi dengan volume sampah memenuhi sungai sepanjang 500 meter (Wijaya, 2019).

Walaupun selama Pandemi Covid-19 terjadi trend penurunan volume sampah di beberapa daerah namun berbanding terbalik dengan volume sampah plastik yang semakin meningkat di Jabodetabek (Dewi, 2020). Oleh karena itu, kami mengusung: "Pengembangan Pojok Ekoliterasi Melalui Pemanfaatan Ecobrick Sebagai Upaya Menanggulangi Darurat Sampah Selama Pandemi COVID-19 Di SDN Kayuringin Jaya VI".

Pojok ekoliterasi menjadi langkah nyata dalam upaya menumbuhkan kecintaan dan kepedulian siswa SD terhadap lingkungan melalui pemanfaatan batu bata plastik atau lebih dikenal dengan istilah "ecobrick". Sehingga siswa dapat menjadikan sistem alam sebagai bagian penting dalam kehidupannya (Sani Aryanto \& Syaodih, 2017) (Bikdeli et al., 2020).

Sasaran kegiatan ini adalah 109 siswa dari kelas IV, V dan VI beserta 11 Guru SDN Kayuringin Jaya VI yang berlokasi di Jl. Cendrawasih Raya No. 1, RT. 023 /RW. 004, Kel. Kayuringin Jaya, Kec. Bekasi Selatan, Kota Bekasi, Jawa Barat 17144. Sekolah ini menjadi sasaran yang paling tepat dan kini telah dikembangkan pojok ekoliterasi yang diharapkan mampu menginspirasi sekolah lain untuk dapat mengembangkan program yang serupa. Maka dari itu, semoga pengabdian yang telah dilaksanakan menjadi langkah awal dalam memupuk jiwa ekoliterasi pada diri siswa SD sehingga menjadi pribadi yang mencintai dan menghargai alam.

\section{Metode Pelaksanaan}

Secara khusus, metode yang digunakan secara proses pelaksanaan pengabdian ini adalah metode scaffolding melalui pendekatan kontrutivisme yang secara teknis diinterpretasikan dalam bentuk kegiatan partisipatif. Namun selama pelaksanaan tetap 
mengupayakan dengan standar protokol Covid-19 melalui aktivitas daring atau luring dengan standarisasi aturan yang ketat, karena program pelatihan ini dilakukan sebagai upaya asistensi peserta didik SD dalam membuat ecobrick yang memiliki nilai guna dan jual sehingga diharapkan mampu merepresentasikan konsep ecopreneurship secara praktis sebagai langkah preventif dan kuratif penanganan permasalahan darurat sampah di Kota Bekasi. Berikut adalah tahapan pelaksanaan program pengabdian yang akan dilaksanakan dalam tiga tahap utama diantaranya (1) Pra-Pelaksanaan (2) Pelaksanaan (3) Evaluasi dan Pelaporan yang dilakukan selama satu tahun.

Lokasi pengabdian masyarakat ini berada di SDN Kayuringin Jaya VI yang beralamat di JI. Cendrawasih Raya No. 1, RT. 007 RW. 002, Kel. Kayuringin Jaya, Kec. Bekasi Selatan, Kota Bekasi, Jawa Barat 17144. Lingkungan di sekitar lokasi mitra berada di pemukiman warga yang merupakan golongan ekonomi menengah ke bawah. Sebagian besar warga kurang begitu memperhatikan kebersihan lingkungan sekitar. Apalagi selokan yang berada di dekat lokasi mitra dipandang kumuh dan tidak jarang menjadi alternatif pembuangan sampah.

Sasaran dalam PKM-PM ini adalah siswa kelas IV, V, dan VI di SDN Kayuringin Jaya VI yang berjumlah 109 Siswa dan 11 Guru. Adapun pemilihan jenjang Sekolah Dasar (SD) dianggap sebagai jenjang usia yang tepat dalam menanamkan sikap peduli lingkungan melalui pengembangan pojok ekoliterasi dengan memanfaatkan ecobrick selama pandemi Covid-19 sebagai respon tanggap terhadap permasalahan darurat sampah di Kota Bekasi. Pemilihan jenjang SD dikarenakan secara teoretis usia siswa SD berada tahap operasional kongkret (rentan usia 7-12 tahun) dengan karakteristik "dicirikan pemikiran yang reversible, mulai mengkonfirmasi pemikiran tertentu, adaptasi gambaran yang menyeluruh, melihat suatu objek dari berbagai sudut pandang, mampu melakukan seriasi, dan berfikir kausalitas" (Piaget dalam Santrock, 2012) sehingga dianggap sebagai jenjang usia yang tepat dalam menenanamkan sikap peduli lingkungan.

Dari gambaran mitra di atas, berikut identifikasi dan alternatif pemecahan permasalahan dapat dilihat pada tabel 1

Tabel 1. Identifikasi dan Alternatif Pemecahan Permasalahan

\begin{tabular}{|c|c|c|}
\hline No. & Identifikasi & Alternatif \\
\hline 1. & $\begin{array}{l}\text { Tempat Pembuangan Sampah (TPS) di beberapa } \\
\text { titik di kota Bekasi melebihi kapasitas } \\
\text { penampungan. Walaupun pemerintah telah } \\
\text { memberikan upaya mengatasi permasalahan } \\
\text { melalui penyediaan TPS di beberapa titik. Termasuk } \\
\text { lokasi mitra pengabdian ini yang berdekatan dengan } \\
\text { selokan yang menjadi alternatif tempat membuang } \\
\text { sampah. }\end{array}$ & $\begin{array}{l}\text { Tindakan alternatif yang dilakukan melalui } \\
\text { penyediaan TPS saja tidak cukup, apalagi } \\
\text { membiarkan selokan kotor dan menyumbat } \\
\text { hingga berpeluang menimbulkan musibah } \\
\text { banjir. Oleh karena itu, harus ada tindakan } \\
\text { pencegahan dengan cara penanaman nilai- } \\
\text { nilai dan karakter melalui kegiatan } \\
\text { pembiasaan sejak dini di sekolah dasar } \\
\text { melalui langkah sederhana namun bermakna } \\
\text { seperti, pembiasaan pembuatan ecobrick di } \\
\text { SD. }\end{array}$ \\
\hline
\end{tabular}




\begin{tabular}{clll}
\hline No. & \multicolumn{1}{c}{ Identifikasi } & \multicolumn{2}{c}{ Alternatif } \\
\hline 2. & Kurangnya pengetahuan mengenai pengolahan \& & Memberikan sosialisasi dan penyuluhan \\
& pemanfaatan sampah plastik di sekolah mitra & mengenai pemanfaatan sampah plastik & yang \\
& & melalui pembuatan ecobrick & dikembangkan menjadi pojok ekoliterasi \\
\hline 3. & Perpustakan di sekolah mitra kurang memadai & Dibuatnya pojok ekoliterasi sebagai alternatif \\
& & pengganti perpustakaan & \\
\hline 4. & Upaya peningkatakan literasi membaca dan menulis & Pojok ekoliterasi menjadi solusi dalam \\
& di Sekolah Dasar (SD) & meningkatkan minat baca siswa menjadi jauh \\
\hline 5. & Sekolah mitra belum memiliki program unggulan & Pojok ekoliterasi dapat dijadikan program \\
& dalam hal peningkatan literasi & unggulan bagi sekolah mitra dan diharapkan
\end{tabular}

Sumber: Hasil Pelaksanaan (2021)

\section{Hasil dan Pembahasan}

\subsection{Detail Program}

Uraian mengenai kegiatan pelaksanaan yang dilakukan untuk penerapan ecobrick menjadi Pojok ekoliterasi tersebut adalah sebagai berikut:

Pelaksanaan Program ini dioptimalkan dalam waktu 4 bulan dengan kegiatan partisipatif melalui program asistensi atau pendampingan secara intensif. Namun selama pelaksanaan tetap mengupayakan dengan melalui aktivitas secara blanded. Berikut gambaran secara umum dapat dilihat melalui Gambar 1
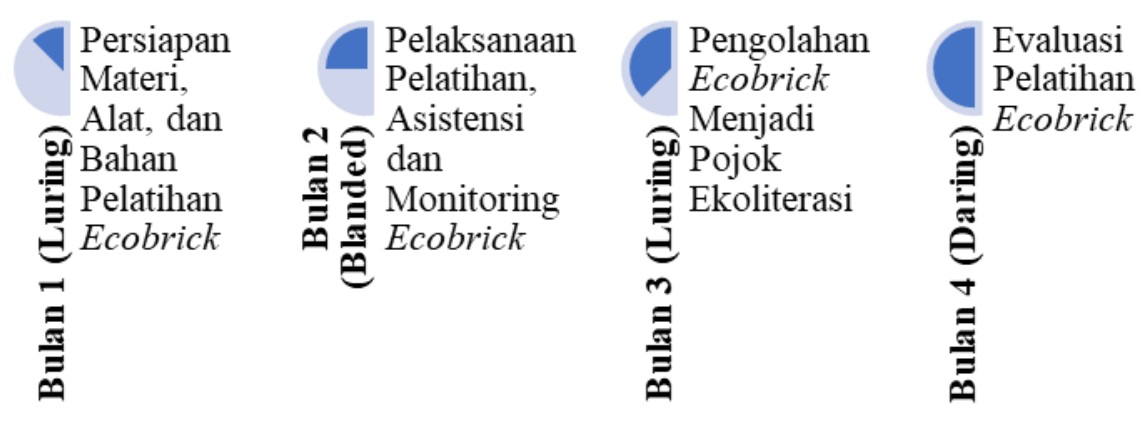

Sumber: Hasil Pelaksanaan (2021)

Gambar 1. Bagan waktu pelaksanaan PKM-PM

Tempat pelaksanaan PKM-PM ini adalah SDN Kayuringin Jaya VI yang berlokasi di Jl. Cendrawasih Raya No. 1, RT. 023 RW. 004, Kel. Kayuringin Jaya, Kec. Bekasi Selatan, Kota Bekasi, Jawa Barat 17144.

\subsection{Tahapan Pelaksanaan Program}

Metode yang digunakan dalam pelaksanaan PKM-PM ini kegiatan partisipatif melalui aktivitas blended dengan mengikuti standar protokol kesehatan Covid-19 yang ketat dan blanded. Berikut tahapan pelaksanaan PKM-PM ini dapat dilihat melalui Gambar 2. 


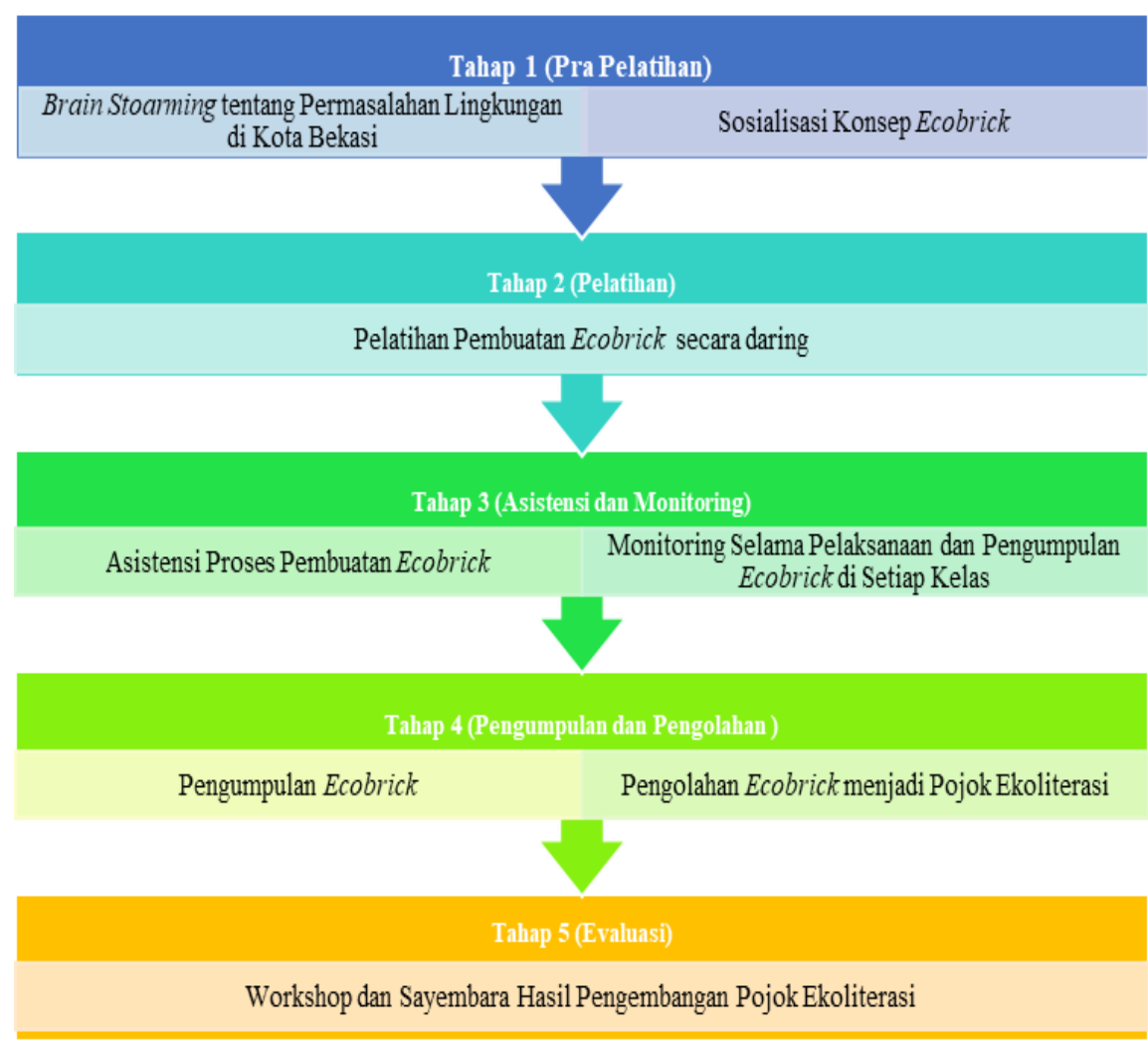

Sumber: Hasil Pelaksanaan (2021)

Gambar 2. Bagan Tahapan Pelaksanaan Program

Pra pelaksanaan/ pelatihan, seluruh siswa diperkenalkan dengan berbagai permasalahan lingkungan alam di Kota Bekasi khususnya permasalahan sampah sebagai bentuk brain stoarming sehingga diharapkan setiap siswa mampu diarahkan untuk mengetahui ecobrick sebagai salah satu solusi menekan volume sampah yang dapat merusak alam. Kegiatan dilakukan secara daring dengan membagikan video kepada siswa/l dan guru untuk memahami hal tersebut. Proses pelaksanaan atau pelatihan mengenai pembuatan ecobrick secara blended dilakukan di rumah masing-masing dengan arahan dari video yang disediakan oleh tim mengenai cara pembuatan ecobrick dan menggunakan peralatan yang telah diberikan oleh tim PKM. Pendampingan dan monitoring tahap ini merupakan tahapan pembinaan dan pengawasan selama program pengabdian berlangsung. Dilakukan secara daring yakni pemantauan berkala oleh tim PKM dengan melihat berbagai kiriman hasil foto dari pelaksanaan saat siswa/l melakukan pembuatan ecobrick. Apabila luring mendatangi langsung rumah siswa/l yang sedang melakukan pembuatan ecobrick. Pengumpulan dan pengolahan tahap ini merupakan tahapan yang sangat penting, dimana setiap kelas diharapkan mampu membuat ecobrick dengan hasil yang baik. Apabila jumlah ecobrick dirasakan sudah cukup, maka langkah selanjutnya adalah pengolahan ecobrick menjadi pojok ekoliterasi dan dilaksanakan secara luring. Evaluasi pelatihan secara daring evaluasi pelatihan dilakukan secara luring dalam bentuk sayembara atau kompetisi antar kelas dengan uji kelayakan ecobrick yang telah dibuat. 


\subsection{Petunjuk Operasional}

Cara pembuatan ecobrick menjadi pojok ekoliterasi dapat dilihat pada Gambar 3.

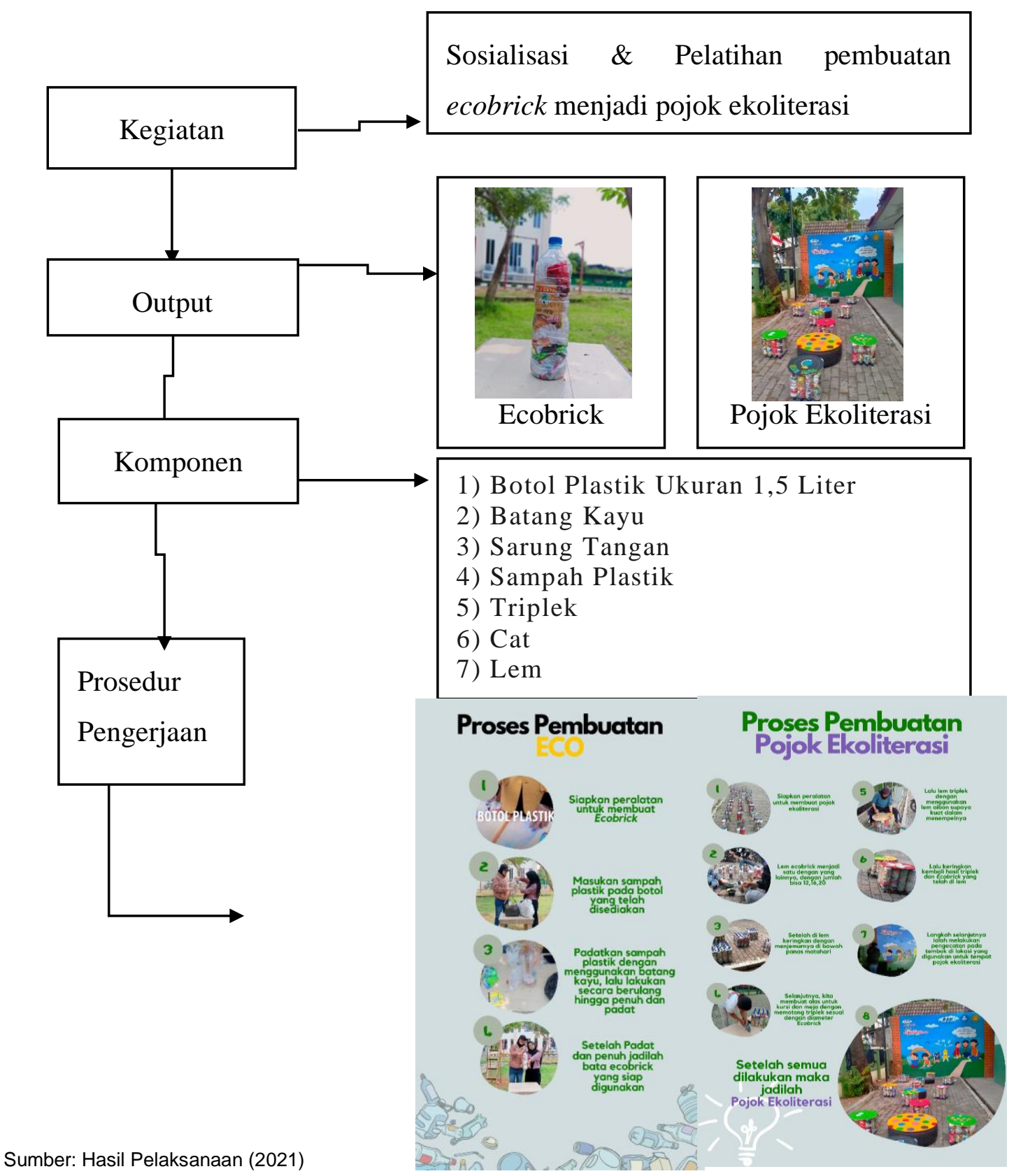

Gambar 3. Bagan Petunjuk Operasional

\subsection{Hasil Penerapan}

Hasil penerapan dapat dilihat dari target yang telah dicapai. Lebih jelasnya gambaran setiap yang telah dicapai dapat dilihat melalui Tabel 2. 
Tabel 2. Hasil Capaian

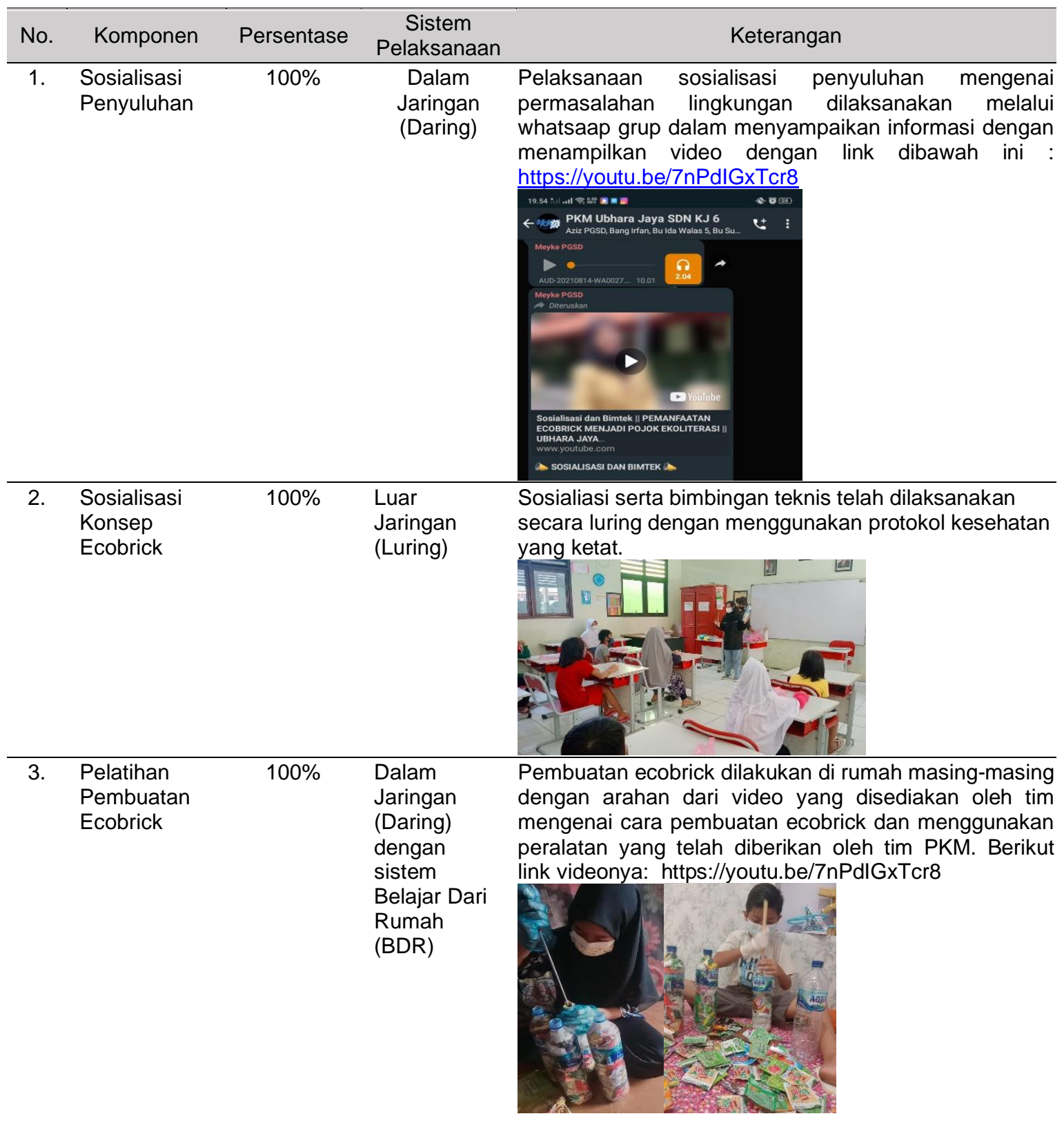

\begin{tabular}{llll}
\hline 4. Asistensi \& & Blended \\
Monitoring \\
Pembuatan \\
Ecobrick
\end{tabular}




\begin{tabular}{|c|c|c|c|c|}
\hline No. & Komponen & Persentase & $\begin{array}{c}\text { Sistem } \\
\text { Pelaksanaan }\end{array}$ & Keterangan \\
\hline & & & & $\begin{array}{l}\text { Pengumpulan Ecobrick dilakasanakan secara Luring di } \\
\text { Sekolah dan dilakukannya sistem per sesi serta } \\
\text { mematuhi protokol kesehatan. }\end{array}$ \\
\hline 6. & $\begin{array}{l}\text { Pengolahan } \\
\text { Ecobrick } \\
\text { menjadi } \\
\text { Pojok } \\
\text { Ekoliterasi }\end{array}$ & $100 \%$ & $\begin{array}{l}\text { Luar } \\
\text { Jaringan } \\
\text { (Luring) }\end{array}$ & $\begin{array}{l}\text { Pengolahan dilakukan dari mulai proses menyatukan } \\
\text { ecobrick sampai dengan proses pembuatan pojok } \\
\text { ekoliterasi }\end{array}$ \\
\hline 7. & $\begin{array}{l}\text { Webinar: } \\
\text { Diseminasi } \\
\text { Pojok } \\
\text { Ekoliterasi } \\
\text { Pada } \\
\text { Masyarakat } \\
\text { Umum }\end{array}$ & $100 \%$ & $\begin{array}{l}\text { Dalam } \\
\text { Jaringan } \\
\text { (Daring) }\end{array}$ & 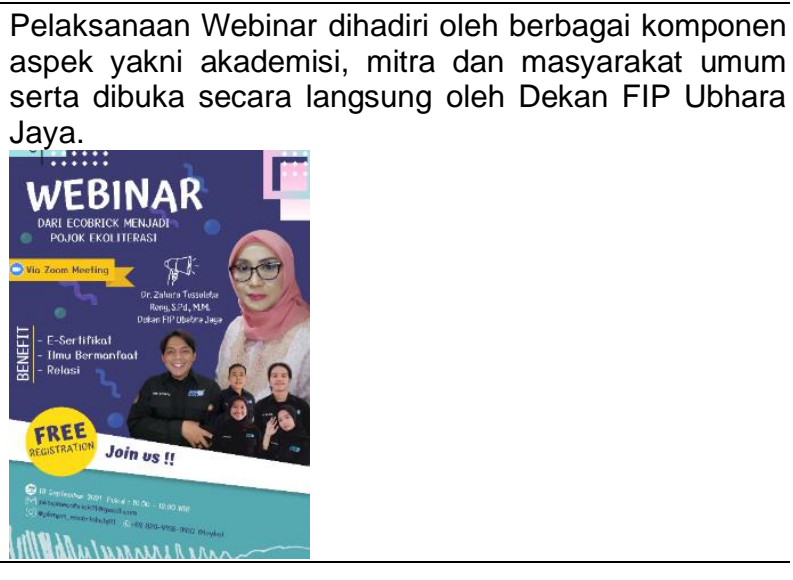 \\
\hline
\end{tabular}

Sumber: Hasil Pelaksanaan (2021)

\section{Kesimpulan}

Hasil pengabdian ini membuktikan bahwa penanggulangan sampah dapat dilakukan dengan cara yang sederhana namun bermakna. Salah satunya melalui cara kreatif dan inovatif melalui pemanfaatan sampah menjadi ecobrick yang dikembangkan menjadi pojok ekoliterasi. Dalam proses pengembangannya, kegiatan pembuatan ecobrick yang ditujukan pada siswa dan guru SD terbilang mudah dan murah, sehingga kegiatan ini bisa dijadikan alternatif budaya sekolah dalam upaya memelihara dan pemanfaatan lingkungan dengan cara mengubah polusi menjadi solusi melalui ecobrick dan dapat pula menjadi sarana peningkatan literasi siswa melalui pojok ekoliterasi. Pengabdian ini menjadi opsi cerdas bagi pihak-pihak yang terlibat di dunia pendidikan dalam mengembangkan program inovatif penanggulangan sampah yang memiliki nilai-nilai pendidikan dan kepedulian terhadap lingkungan, serta diharapkan dapat menjadi projek percontohan bagi sekolah-sekolah lainnya. Dalam rangka memperluas informasi terkait dengan hasil pengabdian ini, kami juga mengembangkan panduan khusus yang lebih mudah diakses oleh masyarakat melalui panduan, artikel ilmiah, video di youtube, dan pembuatan HAKI sebagai penguatan atas konsep yang telah dijalankan

\section{Ucapan Terimakasih}

Penulis mengucapkan terima kasih kepada semua pihak yang terlibat dalam kagiatan abdimas ini terutama pihak kemendikbud dikti yang telah memberikan ruang dan kesempatan untuk berdaya dan berkarya di Program Kreativitras Mahasiswa Bidang Pengabdian Pada 
Masayarak (PKM-PM). Disamping itu penulis mengucapkan terimakasih kepada segenap pimpinan dan seluruh Civitas Akademika Universitas Bhayangkara Jakarta Raya yang terlah memberikan batuan materil maupu moril. Dan yang paling penting kami mengucapkan terimakasih sebesar-besarnya kepada pihak mitra di SDN Kayuringin Jaya VI yang sudah berkenan menjadi mitra pengabdian ini. Semoga kebaikan pihak-pihak yang mendukung kegiatan ini dapat ganjaran dari Allah SWT.

\section{Daftar Pustaka}

Aryanto, S. (2016). The Implementation of Edupreneurship Based on Local Wisdom in Primary School as an Effort to Prepare Indonesian Golden Era. Education in the 21st Century :Responding to Current Issues, 787-793.

Aryanto, Sani. (2016). Pengembangan Studentpreneurship Berbasis Local Wisdom di Sekolah Dasar Sebagai Upaya Menyiapkan Generasi Emas Tahun 2045. Prosiding PGSD Universitas Kuningan, 1(1), 430-439.

Aryanto, Sani, \& Syaodih, E. (2017). Development of Ecoprenuership in Primary School. International E-Journal of Advances in Education, Turkey, 3(99), 597-602.

Bikdeli, B., Madhavan, M. V., Jimenez, D., Chuich, T., Dreyfus, I., Driggin, E., Nigoghossian, C. Der, Ageno, W., Madjid, M., Guo, Y., Tang, L. V., Hu, Y., Giri, J., Cushman, M., Quéré, I., Dimakakos, E. P., Gibson, C. M., Lippi, G., Favaloro, E. J., ... Lip, G. Y. H. (2020). COVID19 and Thrombotic or Thromboembolic Disease: Implications for Prevention, Antithrombotic Therapy, and Follow-Up: JACC State-of-the-Art Review. Journal of the American College of Cardiology, 75(23), 2950-2973. https://doi.org/10.1016/j.jacc.2020.04.031

Dewi, R. K. (2020). Mengapa Pandemi Corona Picu Lonjakan Limbah Plastik di Asia Tenggara?. Kompas.Com. https://www.kompas.com/tren/read/2020/08/10/070000165/mengapa-pandemi-coronapicu-lonjakan-limbah-plastik-di-asia-tenggara?page=all

Kiky, A. (2020). Manajemen Resiko terhadap Black Swan Event Maret 2020 di Indonesia. Studi Kasus Efek Covid-19 Terhadap Pasar Modal Indonesia. Jurnal Bina Manajemen, 8(2), 90105.

Kurnia, N. (2020). Sampah Menjadi Masalah Lingkungan di Indonesia. Kompasiana. https://www.kompasiana.com/niningkurnia/5cbef26595760e2b081e54a4/sampah-menjadimasalah-lingkungan-di-indonesia

Oktapianto. (2016). Peningkatan Ekoliterasi Siswa dalam Pemanfaatan Sampah Kertas dengan Model Project Based Learning pada Pembelajaran IPS. Sekolah Pascasarjana Universitas Pendidikan Indonesia.

Pahrevi, D. (2019). Sampah Menggunung 20 Meter, TPA Burangkeng Bekasi "Overload". Kompas.Com. https://megapolitan.kompas.com/image/2019/01/21/19182811/sampahmenggunung-setinggi-20-meter-tpa-burangkeng-bekasi-overload 
Prasetyo, K. (2014). NGenerasi Emas 2045 sebagai Fondasi Mewujudkan Siklus Peradaban Bangsa Melalui Implementasi Kurikulum 2013 di Sekolah Dasaro Title. Seminar Nasional Kurikulum 2013 Di Universitas Tanjungpura Pontianak.

Sanchis-Gomar, F., Lavie, C. J., Mehra, M. R., Henry, B. M., \& Lippi, G. (2020). Obesity and Outcomes in COVID-19: When an Epidemic and Pandemic Collide. Mayo Clinic Proceedings. Mayo Foundation for Medical Education and Research, 95(7). https://doi.org/doi: 10.1016/j.mayocp.2020.05.006

Santrock, J. W. (2012). Life-Span Development (Perkembangan Masa Hidup) (13th ed.). Erlangga.

Singh, R., \& Subedi, M. (2020). COVID-19 and Stigma: Social discrimination towards frontline healthcare providers and COVID-19 recovered patients in Nepal. Asian Journal of Psychiatry. Elsevier, 53(Juni). https://doi.org/10.1016/j.ajp.2020.102222

Virus Corona: Limbah Infeksius Covid-19 Masih Ditemukan di TPA, Ada Kelonggaran, Pengabaian, Dan Tidak Ada Pengawasan. (2020). BBC News. https://www.bbc.com/indonesia/majalah-54640725

Wijaya, C. (2019). Ratusan Sampah Diangkat dari Kali Pisang Batu, Bekasi. BBC News. https://www.bbc.com/indonesia/indonesia-46806703 